УДК 338.46:621.31

\title{
СОСТОЯНИЕ И НАПРАВЛЕНИЯ РАЗВИТИЯ ТЕОРИИ ЭКОНОМИКИ И УПРАВЛЕНИЯ ЭЛЕКТРОЭНЕРГЕТИЧЕСКИМ КОМПЛЕКСОМ РОССИИ
}

\author{
(C) 2012 г. М. А. Булатенко, Я. И. Тульчинская \\ Национальный исследовательский университет \\ "Московский энергетический институт»
}

В статье анализируются научные работы, направленные на развитие теории и практики управления организациями электроэнергетического комплекса (ЭЭК) РФ в условиях развития конкурентных отношений на энергорынках. Обнаружена взаимосвязь между объектами исследования и уровнем собственного энергопотребления функииональных составляюших ЕЭС России. Выявлена актуальность дальнейшего развития управленческих инноваций в области энергосбережения и повышения энергетической эффективности и построения систем энергетического менеджмента для ЭЭК.

Ключевые слова: теория управления; электроэнергетический комплекс; генерация электроэнергии; электросетевые компании; изолированные энергосистемы; энергосбережение; энергетическая эффективность; инновации.

The paper is devoted to the review of scientific works aimed at the development of the theory and practice of management of the organizations in Russian electric-power industry (EPI) under the conditions of the competitive relations' development in the energy markets. The interrelations between objects of study and the level of their own energy consumption by functional components of Russian EPI were discovered. Authors detected the urgency of further development of management innovation in energy conservation and energy efficiency and building energy management systems for the EPI.

Key words: management theory; electric-power industry; power generation; power grid companies; isolated power; energy conservation; energy efficiency; innovations.

В условиях вступления России во Всемирную торговую организацию одной из наиболее актуальных современных проблем, как на федеральном, так и на региональных уровнях управления, становится проблема повышения конкурентоспособности отечественной экономики. Один из аспектов указанной проблемы - существенное отставание России по уровню энергоэффективности экономики относительно других государств. Отношение потребляемой энергии к ВВП в Российской Федерации (энергоемкость экономики) почти в три раза превышает аналогичный западноевропейский показатель [1].

Повышение эффективности функционирования электроэнергетического комплекса (ЭЭК) России занимает центральное место в решении актуальных социально-экономических задач развития России, таких как снижение уровня техногенной нагрузки на природную среду; повышение национальной безопасности и конкурентоспособности; переход от экспорта сырья к экспорту промышленной продукции и технологий и другие.

Глубокие системные преобразования ЭЭК РФ инициировали научные работы, направленные на развитие теории и практики управления организациями ЭЭК, построение систем управления организациями, в максимальной степени соответствующих осуществленным преобразованием и современным требованиям международных стандартов в области менеджмента.

В результате проведенной реструкту- 
ризации ЭЭК России в настоящее время состоит из ЕЭС России, представленной тремя основными функциональными составляющими (генерация, транспорт и сбыт электроэнергии), и изолированных энергосистем.

Наиболее концентрированно вопросы теории экономики и управления рассмотрены в диссертационных работах, объектом исследования которых являлись экономические системы ЭЭК различного масштаба, уровня, сфер действия и форм собственности. За последнее время в этом направлении было защищено свыше 60 диссертаций на соискание ученой степени доктора экономических наук и кандидата экономических наук по специальности 08.00.05 «Экономика и управление народным хозяйством» (области исследования: экономика, организация и управление предприятиями, отраслями, комплексами; управление инновациями и региональная экономика). Рассмотрим основные научные положения, которые стали предметом исследования российских ученых, условно разделив их по выделенным выше функциональным составляющим, а также имеющих отношение к изолированным энергосистемам, ко всем типам энергокомпаний и электроэнергетике в целом, отдельным потребителям электроэнергии, энергосбережению и повышению энергетической эффективности.

\section{Генерация электроэнергии}

Реформирование электроэнергетической отрасли в первую очередь было направлено на создание конкуренции среди электрогенерирующих компаний, которые стали объектами различных исследований на протяжении достаточно длительного отрезка времени.

При формировании конкурентного рынка среди генерирующих компаний необходимо обеспечить соблюдение принципа относительного равенства стартовых условий каждой территориальной генерирующей компании (ТГК), для этого нужно всю совокупность теплоэлектроцентралей (ТЭЦ) распределить по ТГК, учитывая их конкурентоспособность. В работе Е. В. Щепкина [2] анализируются технологические особенности ТЭЦ, их проблемы и перспективы развития на рынках электро- и теплоэнергии. Автором были классифицированы показатели для оценки конкурентоспособности ТЭЦ и выяв- лены три группы (кластера) конкурентоспособности, основанные на разработанной методике оценки конкурентоспособности ТЭЦ.

Вопросам управления ТЭЦ в условиях развития конкурентных отношений на энергорынках также посвящена работа Д. А. Фрей [3], в рамках которой разработаны методические рекомендации по планированию производственной программы ТЭЦ, в том числе универсальные экономико-математические модели планирования производственно-хозяйственной деятельности ТЭЦ без распределения затрат между электроэнергией и теплом (стратегия «ориентации на конкурентов») и с определением доли затрат, относимых на тепло (стратегия ценообразования «издержки плюс надбавка»).

Значительно влияние на социально-экономическое развитие регионов и страны в целом оказывает реорганизация управления предприятиями атомной энергетики, где наблюдаются повышенные требования к точности экономических оценок при высокой цене ошибки за неверное принятое решение о реализации (отказе от реализации) конкретных инновационных (инвестиционных) проектов. Разработкой систем эффективного управления объектами атомной энергетики занимались В. Д. Секерин [4], Я. Н. Ганзер [5], А. И. Мороз [6], М. Г. Кретов [7].

В. Д. Секерин [4] дал интегральную оценку перехода экономики закрытых административно-территориальных образований на инновационный путь развития, разработал механизм оценки инновационного потенциала и инновационной активности организаций Росатома, выделил наиболее результативные и эффективные инновационные разработки в этом секторе. В работе разработана авторская модель инновационных процессов с тремя взаимосвязанными параллельными ветвями реализации инновационного процесса и многократным механизмом обратной связи для учета постоянных изменений воздействующих факторов и объема знаний в процессе инновационной деятельности в атомной промышленности.

Одним из перспективных направлений развития ЭЭК является использование возобновляемых источников энергии в регионах России. И. Н. Буданов в своей работе [8] в качестве объекта исследования выбрал ги- 
дроэнергетическую отрасль в условиях развивающегося конкурентного рынка электроэнергии. Существующие инструменты управления качеством и конкурентоспособностью были адаптированы автором к особенностям хозяйствования в гидроэнергетике. Ценологический подход к оптимизации структуры хозяйствующих субъектов гидроэнергетической отрасли выявил перспективность развития малой гидроэнергетики, для сокращения издержек которой автором была разработана система управления информационными потоками: как в рамках конкретного хозяйствующего субъекта, так и малой гидроэнергетики в целом.

Энергообъекты нетрадиционной электроэнергетики в качестве объекта исследования выступают в работе Ю. В. Воропановой [9], в которой систематизируется информация по применению возобновляемых источников энергии, а также проводится обзор методик оценки их экономической эффективности. Для лиц, принимающих решение о целесообразности строительства или реконструкции объектов электроэнергетики, автором разработаны следующие методики расчета: величины капитальных вложений в текущих ценах; величины ежегодных эксплуатационных затрат; совокупности показателей экономической эффективности объектов нетрадиционной электроэнергетики. Дальнейшее развитие теории управления нетрадиционной энергетикой нашло отражение в исследовании А. О. Астуфарова [10].

Исследованию и обсуждению различных проблем альтернативной энергетики (в том числе и малой распределенной электроэнергетики) посвящены различные конференции и специализированные научно-технические журналы, например журнал «Малая энергетика».

29 ноября 2012 года прошла вторая Всероссийская конференция «Развитие малой распределенной энергетики в России», на которой были проведены круглые столы:

1. «Вопросы развития региональной энергетики, нормативно-правовое регулирование малой распределенной энергетики» под руководством К. К. Ильковского;

2. Технологическая платформа «Малая распределенная энергетика»: «Прорывные технологии, механизмы финансирования раз- работок, проблемы, пути развития» под руководством О. А. Новоселовой;

3. «Вопросы государственной поддержки малой распределенной энергетики, механизмы проектного финансирования, тарифообразование и организация розничных рынков тепловой и электрической энергии» под руководством Д. Нюшлосса.

В работе Р. С. Шакирова [11] разработан методический подход к управлению интегрированными образованиями малой энергетики и отражены перспективы их развития.

На основе анализа предпринимательской среды Е. О. Демидовой [12] выделены ключевые факторы развития предпринимательства в малой энергетике и разработаны стратегические сценарии развития предпринимательских структур малой энергетики.

В ходе реструктуризации электроэнергетической отрасли наметился дефицит энергетических мощностей и общее старение производственных фондов при одновременном росте количества генерирующих компаний и ограничения их финансовых возможностей. В условиях конкурентного рынка наиболее важным является получение максимального эффекта от использования инвестиций в кратчайшие сроки. В диссертационной работе К. А. Куликовой [13] разработана модель формирования инвестиционной программы генерирующей компании в условиях ограниченности финансовых ресурсов. В работе использовано имитационное моделирование по методу Монте-Карло для оценки возможных изменений показателей эффективности проекта, учета неопределенности влияний внешней среды и анализа риска инвесторов. Итоговым показателем эффективности выбрана концепция экономической добавленной стоимости (EVA). Автором реализована надстройка в отраслевом программном комплексе оценки эффективности «ENERGYINVEST» (OOO «НЦПИ»).

Я. И. Тульчинская [14] проанализировала международный опыт и разработала механизм стимулирования инвестиций в строительство электрогенерирующих предприятий в условиях формирования и функционирования оптового рынка электроэнергии и мощности России. Автором сформулированы приоритеты инвестиционной стратегии, структурированы и классифицированы 
инструменты стимулирования инвестиций, a также предложена авторская программа успешного внедрения механизма стимулирования инвестиций в строительство электрогенерирующих предприятий в России.

Р. В. Пыхтин [15] разработал методы выбора стратегии роста и конкурентной стратегии, на их основе предложил методику формирования политики ценообразования для генерирующих электроэнергетических предприятий различных типов, учитывающую прогноз роста электропотребления, структуру рынка электроэнергии, правила функционирования оптового и розничного рынка электроэнергии, существующие тарифы на электроэнергию.

С целью обеспечения устойчивого экономического развития энергогенерирующих компаний Г. А. Кичигина [16] предложила преобразовать функционально-линейные структуры управления в дивизионный менеджмент по технологическим системам, управление стоимостью которых (и определения величины необходимых инвестиций) будет осуществляться на основе автоматизации многопараметровых производственных процессов. Для появления конкурентных преимуществ у инновационной генерирующей компании нужно обеспечить мотивацию инновационной деятельности на микроэкономическом уровне компаний.

\section{Транспорт электроэнергии}

На основе системного подхода О. В. Тихомировой [17] классифицированы факторы, влияющие на эффективность функционирования региональных электросетевых компаний (РСК), основным из которых является реконструкция и строительство новых объектов электросетевого хозяйства, требующие существенных капитальных вложений. По мнению автора, систему государственного тарифного регулирования «затраты +» необходимо заменить на новую, предполагающую создание благоприятных условий для привлечения инвестиций, стимулов для эффективного управления компанией и взаимовыгодных отношений с потребителями услуг РСК. Разработана модель регулирования тарифов для потребителей, присоединенных к сетям РСК, на основе формирования стратегии развития, базирующейся на клиентоориентиро- ванном подходе: согласования инвестиционных планов развития и стоимости услуги по передаче и присоединению каждого потребителя и РСК. Для расчета дифференцированных тарифов РСК может идентифицировать свои затраты на передачу электроэнергии по классифицированным группам потребителей, выделенным по следующим признакам: конфигурация сетей, особенности подключения, режим потребления.

Для привлечения внешних инвестиций в электросетевой комплекс государственные органы власти разработали и ввели в действие новую систему тарифообразования по методу доходности инвестированного капитала - метод RAB (от англ. Regulatory Asset Base), согласно которому в тариф на передачу электрической энергии включались обоснованные затраты электросетевой компании, возврат инвестируемого капитала и определенный доход на вложенные средства. По данной системе одним из важных критериев оценки электросетевых компаний является эффективность использования основного капитала.

Анализ и совершенствование структуры инвестиционных вложений электросетевых компаний (ЭСК) в новых условиях тарифного регулирования приведен в исследованиях П. И. Оклея [18]. Автор предлагает скорректированную методику оценки эффективности инвестиционных вложений, учитывающую дополнительный эффект от экономии операционных затрат и снижения потерь электроэнергии, возникающего в связи с реализацией инвестиционной программы. Разработана авторская финансово-экономическая модель ЭСК с возможностью формирования источников финансирования инвестиционных вложений в зависимости от их объема и возможностью учета тарифных последствий в зависимости от ежегодного объема инвестиционных вложений. В диссертационной работе был изменен применяемый в настоящее время алгоритм формирования структуры инвестиционных вложений ЭСК, автором было предложено использовать метод упорядоченного перебора всех возможных комбинаций инвестиционных вложений, а в качестве критерия выбрана максимизация совокупного индекса доходности инвестиционных вложений. В ходе разработки скоррек- 
тированной методики оценки эффективности инвестиционных вложений ЭСК автором были получены аналитические зависимости доходности инвестиционных вложений от нормативного срока возврата инвестиций и нормы доходности на инвестированный капитал, что позволяет построить графические зависимости, которые впоследствии можно использовать как инструменты формирования стратегии привлечения заемного финансирования.

Электроэнергетические предприятия распределительно-сетевого комплекса в качестве объекта инвестиционной деятельности выделены также в работах В. В. Быкова [19] и Ю. В. Коршунова [20]. С одной стороны, у сетевых компаний недостаточно финансовых ресурсов для модернизации и ввода новых объектов электросетевого хозяйства, с другой стороны, внешние инвесторы заинтересованы в экономически выгодных инвестиционных проектах. Чтобы привлечь инвесторов и снизить риски инвестирования электросетевым компаниям необходимо исключить невостребованные потребителем проекты и отобрать наиболее выгодные, учитывающие интересы, как самого предприятия, так и региональных (федеральных) властей и внешних инвесторов.

В работе В. В. Быкова [19] разработаны процедура выбора стратегии инвестиционного развития данных предприятий и методика определения вида организации складского хозяйства и его структуры.

В работе Ю. В. Коршунова [20] предложена новая система оценки эффективности инвестиционных проектов ЭСК на основе системы долгосрочного прогнозирования электрических нагрузок. В ней используется модифицированный метод «свертывания критериев», который рассматривает экономические, технологические, экологические, социально значимые и другие важные параметры инвестиционных проектов, определяет один итоговый показатель для отбора. В работе упорядочивается и регламентируется процесс инвестиционного планирования. Проблема информационно-аналитического обеспечения процесса отбора инвестиционных проектов корректной и актуальной информацией о нагрузке конкретных потребителей и загрузке энергетических объектов в любой момент времени решена с помощью ведения электронных баз данных по всем важным для реализации отбора параметрам инвестиционных проектов на основе программного обеспечения SAP.

Для повышения эффективности управления РСК в работе Р. А. Асадулина [21] сформированы требования к информационной системе менеджмента электросетевой компании и методы систематизации информации о деятельности электросетевой компании. Также проанализированы существующие системы показателей для управления компаниями, выявлены их преимущества и недостатки применительно к электроэнергетической отрасли, выработан единый подход к созданию интегрированной системы показателей, которая позволяет получить количественную взаимосвязь оперативных и стратегических показателей деятельности РСК с применением бенчмаркинга и отражены возможные варианты использования системы на практике.

М. А. Мирошниченко [22] разработала процессную модель системы управления РСК, основанную на интегрированной системе менеджмента, составной частью которой является подсистема стратегического контроллинга. Последняя, в свою очередь, обеспечивает поддержку процессов достижения стратегических и оперативных целей компании, среди которых и социально-экологические, учитывающие интересы стейкхолдеров организации.

В исследованиях А. В. Антропенко [23] разработаны инновации в системе управления процессами ремонтов оборудования в электросетевых компаниях (ЭСК). Произведена оценка экономической эффективности сформированного нового механизма оценки стоимости ремонтов энергетического оборудования, который (в отличие от традиционного в системе планово-предупредительного ремонта) оценивает стоимость каждой операции декомпозированного процесса ремонта оборудования с учетом динамического изменения экономической среды и разработанного принципа интегрального формирования сметной стоимости ремонта оборудования. Для повышения эффективности функционирования ЭСК предлагается сначала инвестиционные вложения направить на ремонт оборудования, а оставшуюся часть на прио- 
бретение нового. Для повышения инвестиционной привлекательности ЭСК руководству компании предложено транслировать заинтересованным лицам свои подтвержденные достижения.

\section{Сбыт электроэнергии}

С целью снижения перекрестного субсидирования и повышения платежной дисциплины потребителей в своих исследованиях А. И. Метляхин [24] дополнил действующую систему тарифов в электроэнергетике тарифами, дифференцированными по срокам платежа, которые создают взаимовыгодные отношения сбытовой компании и потребителей путем оптимизации дебиторской задолженности и изменения сбытовой надбавки. Автором разработана имитационная модель обоснования тарифов на электроэнергию, с помощью которой можно планировать сбытовую надбавку при формировании индивидуального тарифа, также можно вычислить оптимальный размер среднего срока предоплаты для каждого отдельного потребителя.

Объектом диссертационного исследования Д. Ю. Фёдорова [25] является инновационная деятельность энергосбытовых компаний в сфере энергосбережения. Автором предложена новая организационная структура и набор дополнительных функций для региональных энергосбытовых компаний, чтобы данные организации могли осуществлять комплексную информационную поддержку инновационной деятельности в области энергосбережения. Также в работе описана модель организации мониторинга инноваций и резервов энергосбережения.

\section{Изолированные энергосистемы}

В работе А. Н. Брусницына [26] рассматриваются энергоресурсосберегающие энерготехнологии на базе органического топлива и возобновляемых источников энергии, а также водородные энерготехнологии. Построен бизнес-ценоз «Изолированные энергосистемы России» и установлена его высокая устойчивость к реализации инновационных проектов генерирующих мощностей. Разработанные методологические подходы по оценке возможностей управления конкурентоспособностью инновационных проектов на базе энергоресурсосберегающих технологий производства электроэнергии показывают, что в условиях изолированных энергосистем, где устанавливаются высокие цены на органическое топливо, тарифы на электроэнергию для инновационных проектов независимой генерации не превышают себестоимости электроэнергии гарантирующего поставщика, и электростанции на базе возобновляемых источников энергии (ВИЭ) могут реализовать возможности диверсификации продукции (например, электроэнергия + электролизный водород).

В диссертационном исследовании К. К. Ильковского [27] проведен анализ возможности применения различных видов технологических инноваций в области изолированных энергосистем, наиболее целесообразным выделено строительство автономных децентрализованных систем малой мощности на базе автономных газовых котельных, а также адаптивных систем электро- и теплоснабжения на основе применения блочномодульных установок. Автором диссертационного исследования предложены организационно-экономические механизмы стимулирования инновационного развития изолированных энергосистем: а) государственная правовая поддержка частных производителей электроэнергии - в части приобретения у них излишков производимой энергии; б) трансформация системы перекрестного тарифного субсидирования в государственную финансовую поддержку малообеспеченных потребителей; в) государственная нормативно-правовая поддержка внедрения и со-финансирования инклюзивных бизнес-моделей в изолированных энергосистемах. Также в работе предложена авторская схема единого информационного пространства поддержки изолированных энергосистем.

\section{Исследования, относящиеся ко всем типам энергокомпаний и электроэнерге- тике в целом}

Главной целью стратегии каждой энергокомпании является создание добавленной стоимости, что удовлетворяет интересы всех ключевых групп заинтересованных лиц. Д. И. Тимофеевым [28] проведен анализ стратегий и соответствующих финансовых результатов энергетических компаний и предложены подходы к развитию техниче- 
ского и организационного потенциала предприятий на основе применения ресурсных теорий стратегического планирования. Автором приводится структура ключевой компетенции фирмы, основанной на способности компании производить в более сжатые сроки и с более низкими затратами по сравнению с конкурентами. По мнению автора, чтобы обеспечить социально-экономическое развитие региона, корпоративная стратегия энергокомпаний должна основываться на ресурсном подходе и сбалансированной оценке акционерной и общественной стоимости.

Особенностям реформирования электроэнергетики России в целом и вопросам государственного регулирования отрасли посвящены исследования К. Б. Вакулевич [29]. В работе описаны основные тенденции преобразования системы управления электроэнергетикой, обоснована необходимость реформирования отрасли в РФ и выделены соответствующие основные проблемы: дефицит инвестиций, затратный механизм установления тарифов, износ оборудования, угрозы энергобезопасности страны, отсутствие стимулов для решения социальных и экологических задач. Сделан вывод о необходимости создания уникальной российской модели развития электроэнергетики, не повторяя полностью, а только опираясь на зарубежный опыт, оставляя значимую роль в развитии рыночных отношений за государством.

В связи с реформированием отрасли государственная компания ОАО РАО «ЕЭС России» прекратила свое существование, но государство по прежнему отвечает перед потребителями за бесперебойное электроснабжение и за развитие электроэнергетики. Один из подходов к формированию организационно-экономического механизма государственного регулирования перспективного развития электроэнергетической отрасли предложен в работе С. П. Макухи [30]. Автором дана оценка роста индексов цен промышленности при росте тарифов на электроэнергию, показано, что рост реальной цены на электроэнергию (сверх инфляции) приводит к снижению ВВП, что в свою очередь приводит к дополнительному росту инфляции. Таким образом, целесообразно снижать инвестиционную нагрузку на тариф на электроэнергию, за счет использования государственного инвести- ционного фонда, предоставления налоговых льгот, применение долгосрочных контрактов и тарифов на электроэнергию, привлечение внешних инвесторов. Автором разработаны методики для мониторинга, анализа возможных отклонений и обеспечения адаптивности реализации программы перспективного развития электроэнергетики.

Вопросам создания привлекательного инвестиционного климата в электроэнергетических компаниях посвящена работа В. А. Кононенко [31], в которой уточняются понятия инвестиций и инвестиционной привлекательности, выявляются основные группы инвесторов и основные составляющие инвестиционной привлекательности для энергокомпаний, с учетом их специфики (жесткая зависимость режима работы предприятия от режима потребления энергии). Для формирования обоснованной инвестиционной политики автором был использован интегральный показатель, учитывающий инвестиционную привлекательность региона на основе рейтинговой оценки и требований внешних инвесторов, разработана методика формирования рейтингового показателя оценки инвестиционной привлекательности (с учетом составляющих управления инвестиционной привлекательностью компании: информационная прозрачность, финансовое состояние, уровень менеджмента компании). Также в работе автором представлен весь комплекс управленческих решений в механизме создания и развития инвестиционно-привлекательного климата для энергопредприятий, с помощью которого можно оценить сильные и слабые стороны предприятия, выявить внешние и внутренние факторы, влияющие на инвестиционную привлекательность, сформировать инвестиционную стратегию.

Е. В. Варфоломеев [32] установил взаимосвязь инновационного развития, экологической политики и процесса капитализации компании, выделил факторы увеличения рыночной стоимости компании при реализации инновационной и эко-политик: сокращение природоохранных платежей, сокращения затрат на ТЭР (так как возрастает энергоэффективность производства), увеличение социальных инвестиций и рост рыночного спроса на акции (за счет участия компании в решении глобальных экологических проблем, 
принятия международных природоохранных стандартов, соответствия законодательству в области охраны окружающей среды).

В диссертационной работе М. К. Агеева [33] разработаны следующие методические основы инновационного организационного развития: алгоритм выявления управленческих проблем, база диагностических вопросов, база типовых управленческих проблем, алгоритм проектирования и совершенствования инновационных систем управления, управление инновационным развитием организации, алгоритм системы контроля организации, внедрение инновационных решений в практику управления организаций.

Развитие розничного рынка электрической энергии, его основные модели и ценообразование на нем, а также формирование инновационный платформы для его развития рассматривается в работе В. А. Косоротова [34]. В ней анализируются особенности управленческого учета издержками и учетных политик энергопредприятий, наиболее детально рассматривается коммерческий учет и коммерческие потери электроэнергии. Для баланса интересов между субъектами розничного рынка электроэнергии автором разработан инновационный организационнофинансовый механизм, включающий создание биллинговой компании в виде некоммерческого партнерства (организует договорные и финансовые отношения на рынке), реализация систем учета затрат при формировании выручки от реализации электрической энергии и затрат при передаче электрической энергии по электрическим сетям (приводят к снижению издержек при передаче электрической энергии по электрическим сетям и ликвидации коммерческих потерь).

Рост значимости и направления развития региональной энергетики определены в работах В. В. Ворожихина [35] и С. Э. Исмаилова [36]. В. В. Ворожихиным сформированы основные принципы формирования региональной энергетической политики, которые обеспечат повышение экономической эффективности отрасли и снизят экологические нагрузки при одновременном поддержании на текущем уровне, в дальнейшем и повышении, надежности и качества энергообеспечения. Разработаны финансово-экономические, нормативно-правовые и организа- ционно-структурные механизмы реализации стратегии развития региональной энергетики. Автором предложена инновационная система тарифообразования «Система эластичного регулирования», определяющая тариф на электрическую энергию по максимуму валового регионального продукта. Для частно-государственного партнерства в сфере региональной энергетики предлагается сформировать долевую собственность в энергокомпаниях, таким образом, разделив акции между региональными администрациями и потребителями. Автором сформирована новая организационная структура - вертикально-интегрированная компания с внешними подразделениями (ВИК - ВП).

Необходимость замены прямого бюджетного финансирования отрасли отображена в работе Д. А. Андрюшина [37], в ней разработана новая концепция системы привлечения заемных средств, а также для обеспечения ее стабильного функционирования предложен инновационный подход к управлению заемной деятельностью.

\section{Отдельные потребители, в частности, ЖКХ}

Во всех городах и практически во всех населенных пунктах возникают потребности в услугах предприятий жилищно-коммунального хозяйства (ЖКХ). Данная отрасль оказывает огромное влияние на макроэкономическую ситуацию в стране и является одним из самых значимых секторов экономики Российской Федерации, в бюджеты каждого субъекта РФ закладываются большие расходы на функционирование пространственно отдаленных друг от друга предприятий ЖКХ. В условиях рыночной экономики наиболее остро встает вопрос об эффективном рациональном управлении ЖКХ для обеспечения безубыточной работы отрасли.

Исследованию проблем формирования эффективного информационно-экономического механизма управления предприятиями ЖКХ в условиях рыночной экономики посвящена работа Ю. В. Гнездовой [38]. Автором рассмотрены особенности отрасли, существующие системы управления ЖКХ, уровень обеспеченности руководителей достоверной информацией и возможности для интеграции предприятий ЖКХ для максимального 
использования их потенциала. Разработана методика поэтапного внедрения маркетинговой информационно-аналитической системы жилищно-коммунального хозяйства.

Реформирование ЖКХ тесно связано с реформированием электроэнергетической отрасли через коммунальную энергетику, где в условиях рыночной экономики необходимо изменение механизмов управления энергопредприятиями ЖКХ. Данным вопросам посвящены диссертационные исследования И. В. Булавина [39] и А. В. Гончарова [40].

Также стоит отметить, что ЖКХ является одним из крупнейших потребителей энергоресурсов в стране. И в данной отрасли отмечается высокий износ основных фондов, значительные объемы потерь электрической и тепловой энергии, недостаточное использование энергосберегающих технологий.

В настоящее время наиболее актуальны вопросы, связанные с организацией инновационной деятельности по энергосбережению в ЖКХ. Им посвящены современные исследования, такие как работа А. А. Балябиной [41], в которой разработана рациональная организационная структура реализации инновационных проектов в ЖКХ с участием малых инновационных предприятий при бюджетных учреждениях. Предложены инструменты стимулирования инновационной деятельности в ЖКХ, процедура и критерии их выбора для выявления инновационных проектов, соответствующих заданным целям (энергосбережение, модернизация ЖКХ, повышение уровня жизни населения). Для оценки эффективности инновационной деятельности по энергосбережению в ЖКХ автором предложена модель, оценивающая синергетический эффект, возникающий во всей системе ЖКХ при реализации инновационных проектов в ее основных подсистемах. Также автором сформирована структура программы инновационного развития ЖКХ региона и муниципальных образований.

Исследования в области энергосбережения и повышения энергетической эффективности

После принятия Федерального закона №261-Ф3 от 23.11.2009 г. [42] стали наиболее актуальными исследования в области энергосбережения и повышения энергетической эффективности, в частности работы, посвященные энерго- и ресурсосберегающим технологиям, совершенствованию функционирования энергосистем, разработкам механизмов распространения и систем управления инновациями в данной области.

В диссертационной работе В. Н. Апряткина [43] произведена структуризация потерь электроэнергии в распределительных электрических сетях, разработан комплекс организационных мероприятий и экономических механизмов, обеспечивающих управление коммерческими потерями, связанными с хищениями и безучетным потреблением электрической энергии. В рыночных условиях при реализации комплексной программы снижения потерь электроэнергии необходимо активизировать деятельность персонала компании, с этой целью автором была разработана модель участия персонала энергоснабжающей организации по выявлению неучтенного электропотребления. Также автором разработаны принципы взаимоотношений сбытовых и сетевых компаний в решении проблемы снижения потерь электрической энергии.

Вопросы, связанные с разработкой и реализацией стратегий энергосбережения, a также с обеспечением и повышением энергетической эффективности региональных промышленных комплексов (РПК) наиболее полно отражены в диссертационной работе С. А. Михайлова [44]. Автором предложена концепция и основные принципы всеобщего управления энергосбережением (Total energysaving management - TESM), которая позволит в кратчайшие сроки получить максимальный положительный эффект от реализации мероприятий, направленных на повышение энергоэффективности предприятия. Разработан организационно-функциональный метод реализации стратегии энергосбережения в РПК, в рамках которого предложена система стимулирующих мероприятий в области энергосбережения и повышения энергетической эффективности. Для сокращения финансовых расходов промышленных предприятий на проведение энергообследований, автором скорректирована процедура проведения комплексного энергетического обследования РПК путем введения этапа энергетического самоаудита предприятий на основе анализа 
видов потерь ТЭР и системы показателей для оценки резервов энергосбережения.

С. А. Михайловым [44] предложена модель передачи и распространения результатов инновационной деятельности в области обеспечения энергосбережения между различными энергетическими предприятиями. Разработана система ключевых показателей эффективности инвестиций, направленных на обеспечение энергосбережения в РПК, согласующая интересы производителей, передающих предприятий и потребителей ТЭР. Предложены методы построения системы энергетического контроллинга и стратегического управления энергосбережением в РПК, учитывающие особенности социально-экономического развития региона.

Используя системный подход, В. А. Шилин [45] разработал целевую модель, принципы (предложен алгоритм целеполагания) и инструменты (например, государственный заказ на инновации) региональной системы управления инновациями в области энергосбережения и повышения энергетической эффективности, а также процедуру предупреждающих действий и систему контроля, рекомендации для определения стратегии деятельности энергосервисной компании и региональной политики в области энергосбережения.

Для снижения энергоемкости экономики необходим эффективный механизм распространения инноваций в области энергосбережения. Существующие подходы и типы стратегий распространения энергосберегающих инноваций, а также процедура их выбора рассматриваются в исследованиях А. А. Кролина [46]. Автором предложено использовать центры коллективного пользования высокотехнологичным оборудованием и мобильные диагностические лаборатории различных видов и методика оценки эффективности их деятельности. Реализации расширенной процедуры мониторинга эффективности инноваций отображается в модифицированной структуре программы инновационного развития региона. По мнению автора, предприятия должны обозначать свои направления инновационного развития на основе энергосбережения и использования возобновляемых источников энергии в модифицированной структуре энергетического паспорта пред- приятия с соответствующими дополнительными разделами.

Устойчивой мировой тенденцией является рост численности городского населения и количества городов, следовательно, и рост агломераций и доли производимой в них ВВП. В настоящее время Москва и Московская область тесно связаны трудовыми, культурно-бытовыми и производственными связями, наблюдается общее развитие различных видов пассажирского транспорта. Поэтому при разработке подходов к управлению Московской агломерацией нецелесообразно формально разделять Москву и Московскую область.

При непрерывном интенсивном росте удельного энергопотребления большой интерес вызывает работа М. М. Яковлева [47], посвященная повышению энергоэффективности Московской агломерации. Автор проанализировал международный опыт управления энергетической эффективностью в мегаполисах и выделил ключевые направления внедрения инноваций в управлении энергоэффективностью. В исследовании предложены новые термины «валовый продукт агломерации» (ВПА) и «расширенное энергопотребление агломерации» (РЭА), использующиеся в авторском подходе к оценке и анализу энергетической эффективности Московской агломерации на базе внедрения системы энергетического менеджмента, основанном на пообъектном учете вклада городов и субрегионов Московской области в ВПА Московской агломерации, построении комплексных энергетических стратегий и единых целевых программ агломерации.

Одним из самых важных и перспективных направлений в области энергоэффективности XXI века является развитие концепции «Smart Grid» («Смарт Грид») или «интеллектуальная сеть» - превращение Единой национальной (общероссийской) электрической сети (ЕНЭС) и распределительных сетей в активно-адаптивную сеть (ААС). Это подразумевает создание полностью автоматической интеллектуальной многоагентной клиентоориентированной системы мониторинга и управления всей электрической сетью в режиме реального времени с опорой на развитие малой распределенной энергетики (в том числе технологий когенерации и воз- 
обновляемых источников энергии). Общее представление о технологии Smart Grid дают отраслевые научно-технические журналы «Информатизация и системы управления в промышленности» и «Автоматизация и IT в энергетике».

По мнению авторов, наиболее интересными работами, которые посвящены интеллектуальным энергетическим системам, являются труды В. Р. Окорокова [48], А. С. Вертешева [49], Е. Л. Пармухиной [50], Б. Б. Кобец [51], В. В. Ильина [52] и других авторов.

В таблице 1 представлена информация об основных функциональных составляющих (ФС) ЭЭК и некоторых потребителях электроэнергии и количестве диссертационных работ, объектами исследования которых являлись указанные ФС ЭЭК и некоторые потребители.

В столбце 4 таблицы 1 представлена информация о собственном потреблении рассматриваемых объектов. Эта информация необходима для установления корреляции между уровнем собственного энергопотребления рассматриваемых объектов и тем научным интересом, который проявляют ученые к этим объектам.

Система электрогенерации России включает почти 600 электростанций единичной мощностью свыше 5 МВт, представленные тепловыми электростанциями (ТЭС), гидроэлектростанциями (ГЭС) и атомными электростанциями (АЭС) [53]. В таблице 2 представлены основные характеристики электростанций (ЭС) России.

Собственное потребление электроэнергии (столбец 4 таблицы 2) $\mathrm{P}_{\mathrm{C}}$, при известной произведенной электроэнергии $\mathrm{P}_{\Pi}$, и коэффициенте полезного действия (КПД) ๆ, может быть определено по формуле (1):

$$
\mathrm{P}_{\mathrm{C}}=\mathrm{P}_{\Pi}\left(\frac{1-\eta}{\eta}\right)
$$

Анализ информации, представленной в таблице 1, позволяет сделать следующие выводы. Наибольший интерес научных работников привлекает такой объект исследования, как электрогенерирующие компании, что соответствует наибольшему уровню собственного энергопотребления. И наоборот, наименьшее количество работ наблюдается в тех энергокомпаниях ЭЭК, где наименьший уровень собственного энергопотребления.

Проанализировав работы в хронологическом порядке, авторами установлено, что в последние годы (2011-2012 гг.) основными направлениями развития теории экономики и управления являются управленческие инновации в области энергосбережения и повышения энергетической эффективности. При

Таблица 1

Количество диссертационных работ, объектами исследования которых являлись различные ФС ЭЭК и некоторые потребители

\begin{tabular}{|l|l|c|c|}
\hline \multicolumn{1}{|c|}{ № } & \multicolumn{1}{|c|}{ ФС ЭЭК и потребители } & $\begin{array}{c}\text { Кол-во } \\
\text { дисс. }\end{array}$ & $\begin{array}{c}\text { Собственное потребление } \\
\text { электроэнергии, млрд. кВт*ч }\end{array}$ \\
\hline 1 & \multicolumn{1}{|c|}{2} & 3 & 4 \\
\hline 1. & Генерация & 15 & 1581,2 \\
\hline 2. & Транспорт & 7 & 110,0 \\
\hline 3. & Сбыт & 2 & - \\
\hline 4. & Изолированные энергосистемы & 2 & 1731,2 \\
\hline 5. & Электроэнергетика, в целом & 10 & 127,0 \\
\hline 6. & ЖКХ & 4 & - \\
\hline 7. & $\begin{array}{l}\text { Энергосбережение } \\
\text { и энергоэффективность }\end{array}$ & 10 & \\
\hline
\end{tabular}


Таблица 2

Основные характеристики электростанций России

\begin{tabular}{|c|c|c|c|c|}
\hline № & Тип ЭС & $\begin{array}{c}\text { Про-во } \\
\text { электроэнергии, } \\
\text { млрд. кВт*ч }\end{array}$ & КПД, о. е. & $\begin{array}{c}\text { Собственное } \\
\text { потребление } \\
\text { электроэнергии, } \\
\text { млрд. кВт*ч }\end{array}$ \\
\hline 1. & ТЭС & 717,6 & $0,37[54]$ & 1221,9 \\
\hline 2. & ГЭС & 176,8 & 0,9 & 19,6 \\
\hline 3. & АЭС & 145,6 & $0,3[55]$ & 339,7 \\
\hline & Итого & 1040,0 & & 1581,2 \\
\hline
\end{tabular}

этом особое внимание уделяется электроэнергетике удаленных населенных пунктов и агломерациям России. Это вполне объяснимо. Высокие показатели российской экономики по энергоемкости вообще, и электроэнергетического комплекса России в частности, диктуют необходимость решения проблем построения результативных систем энергетического менеджмента для ЭЭК с учетом требований международного стандарта ISO 50001:2011 [56] и специфики функционирования ЭЭК.

\section{Литература}

1. Хабибрахманов Р. Р., Рыюжкова Л. В. Факторы, определяющие энергоемкость отечественной экономики [Электронный ресурс] / Журнал «Управление экономическими системами: электронный научный журнал». - Режим доступа: http://uecs.ru/index. php12(48)/2012, свободный. - Загл. с экрана.

2. Щепкин E. B. Разработка методических основ оценки конкурентоспособности ТЭЦ при формировании территориальных генерирующих компаний: Автореферат дисс. на соиск. уч. степени канд. эконом. наук. М.: МЭИ, 2003. - $20 \mathrm{c}$.

3. Фрей Д. А. Разработка методического обеспечения системы планирования производственно-хозяйственной деятельности ТЭЦ в условиях развития конкурентных отношений на энергорынках: Автореферат дисс. на соиск. уч. степени канд. эконом. наук. - М.: МЭИ, 2007. - 21 с.

4. Секерин В. Д. Управление инновациями в электроэнергетике (на примере Росато- ма): Автореферат дисс. на соиск. уч. степени докт. эконом. наук. - М.: МЭИ, 2007. — 46 с.

5. Ганзер Я. Н. Модели инвестиционного анализа проектов продления сроков эксплуатации энергоблоков атомных станций первого и второго поколения: Автореферат дисс. на соиск. уч. степени канд. эконом. наук. - М.: МЭИ, 2005. - $18 \mathrm{c.}$

6. Мороз А. И. Совершенствование механизма обеспечения конкурентоспособности атомной энергетики России: Автореферат дисс. на соиск. уч. степени канд. эконом. наук. - М.: Моск. акад. экономики и права, 2012. $-23 \mathrm{c}$.

7. Кретов М. Г. Принципы и методы разработки информационной системы эффективного управления проектированием объектов атомной энергетики: Автореферат дисс. на соиск. уч. степени канд. эконом. наук. СПб.: С.-Петерб. гос. политехн. ун-т, 2011. $18 \mathrm{c}$.

8. Буданов И. Н. Современные пути повышения конкурентоспособности гидроэнергетической отрасли: Автореферат дисс. на соиск. уч. степени канд. эконом. наук. М.: Моск. ин-т предпринимательства и права (МИПИ), 2007. - 20 с.

9. Воропанова Ю. В. Методика оценки экономической эффективности инвестиций в объекты нетрадиционной электроэнергетики: Автореферат дисс. на соиск. уч. степени канд. эконом. наук. - Вологда: Вологодский государственный технический университет, 2004. - $18 \mathrm{c}$.

10. Астафуров А. О. Управление замещением традиционной углеводородной энергетики эколого-ориентированной биоэнергети- 
кой: Автореферат дисс. на соиск. уч. степени канд. эконом. наук. - М.: Государственный университет управления, 2012. - 28 с.

11. Шакиров P. C. Адаптация методов управления интегрированными образованиями малой энергетики: Автореферат дисс. на соиск. уч. степени канд. эконом. наук. - М.: ФГОБУ ВПО «Государственный университет Минфина России», 2012. - 29 с.

12. Демидова Е. О. Разработка стратегических сценариев развития предпринимательских структур: на примере предприятия малой энергетики: Автореферат дисс. на соиск. уч. степени канд. эконом. наук. - СПб.: С.-Петерб. гос. ун-т, 2011. - 24 с.

13. Куликова К. А. Экономические модели формирования инвестиционной программы электрогенерирующей компании в условиях реформирования отрасли: Автореферат дисс. на соиск. уч. степени канд. эконом. наук. М.: МЭИ, 2005. - 20 с.

14. Тульчинская Я. И. Разработка механизма стимулирования инвестиций в строительство электрогенерирующих предприятий в рамках оптового рынка электроэнергии и мощности России: Автореферат дисс. на соиск. уч. степени канд. эконом. наук. - М.: МЭИ, 2009. - 20 с.

15. Пьхтин Р. В. Выбор стратегий развития генерирующих электроэнергетических предприятий в условиях формирования конкурентного рынка электроэнергии (на примеpe Смоленской области): Автореферат дисс. на соиск. уч. степени канд. эконом. наук. М.: МЭИ, 2007. - 19 с.

16. Кичигина Г. А. Формирование инновационной среды в энергогенерирующей компании: Автореферат дисс. на соиск. уч. степени канд. эконом. наук. - М.: МЭИ, 2010. - $21 \mathrm{c}$.

17. Тихомирова О. В. Методическое обеспечение системы тарифного регулирования региональных электросетевых компаний на основе клиентоориентированного подхода: Автореферат дисс. на соиск. уч. степени канд. эконом. наук. - М.: МЭИ, 2007. - 23 с.

18. Оклей П. И. Совершенствование структуры инвестиционных вложений электросетевых компаний в целях повышения эффективности основного капитала в новых условиях тарифного регулирования: Авто- реферат дисс. на соиск. уч. степени канд. эконом. наук. - М.: МЭИ, 2011. - 20 с.

19. Быков В. В. Стратегическое управление инвестициями в развитии региональных систем материально-технического обеспечения сетевых электроэнергетических предприятий: Автореферат дисс. на соиск. уч. степени канд. (докт.) эконом. наук. - М.: МЭИ, 2009. - 21 с.

20. Кориунов Ю. В. Методы и процедуры формирования инвестиционной программы электросетевой компании на основе долгосрочного прогнозирования электрических нагрузок: Автореферат дисс. на соиск. уч. степени канд. эконом. наук. - М.: МЭИ, 2009. - 24 c.

21. Асадулин Р. А. Разработка интегрированной системы показателей эффективности управления региональной электросетевой компанией: Автореферат дисс. на соиск. уч. степени канд. эконом. наук. - М.: МЭИ, 2009. - 17 с.

22. Мирошниченко М. А. Разработка системы стратегического контроллинга организации, сфокусированной на стратегию (на примере региональной электросетевой компании): Автореферат дисс. на соиск. уч. степени канд. эконом. наук. - М.: МЭИ, 2010. - $26 \mathrm{c}$.

23. Антропенко A. В. Повышение эффективности работы электросетевой компании за счет внедрения инноваций в систему управления процессами ремонта оборудования (на примере ОАО «МРСК Сибири»): Автореферат дисс. на соиск. уч. степени канд. эконом. наук. - М.: МЭИ, 2010. - 20 с.

24. Метляхин А. И. Прогнозирование и оптимизация тарифов на электроэнергию в региональной экономической системе: Автореферат дисс. на соиск. уч. степени канд. эконом. наук. - М.: МЭИ, 2010. - 20 с.

25. Федоров Д. Ю. Механизм повышения эффективности инновационной деятельности энергосбытовых компаний в сфере энергосбережения: Автореферат дисс. на соиск. уч. степени канд. эконом. наук. - М.: МЭИ, 2012. - $22 \mathrm{c}$.

26. Брусницын A. Н. Возможности инновационного развития изолированных энергосистем на базе энергоресурсосберегающих технологий (на примере энергосисте- 
мы Камчатки): Автореферат дисс. на соиск. уч. степени канд. эконом. наук. - М.: МЭИ, 2010. -20 c.

27. Ильковский К. К. Инновационные механизмы развития малой энергетики энергоизолированных районов: на примере республики Саха (Якутия): Автореферат дисс. на соиск. уч. степени докт. эконом. наук. - М.: Нац. исслед. ун-т «МЭИ», 2012. - 47 с.

28. Тимофеев Д. И. Ресурсный подход к стратегическому планированию развития энергетической компании (на примере ОАО АК «Якутскэнерго»): Автореферат дисс. на соиск. уч. степени канд. эконом. наук. - М.: МЭИ, 2009. - 19 с.

29. Вакулевич К. Б. Особенности экономического развития электроэнергетики в России: Автореферат дисс. на соиск. уч. степени канд. эконом. наук. - М.: МЭИ, 2005. - 20 c.

30. Макуха С. П. Организационно-экономический механизм государственного регулирования перспективного развития и инвестиционной деятельности в электроэнергетике: Автореферат дисс. на соиск. уч. степени канд. эконом. наук. - М.: МЭИ, 2009. $20 \mathrm{c}$.

31. Кононенко B. A. Совершенствование экономического механизма создания привлекательного инвестиционного климата в электроэнергетических компаниях: Автореферат дисс. на соиск. уч. степени канд. эконом. наук. - М.: МЭИ, 2009. - 19 с.

32. Варфоломеев Е. В. Совершенствование методов оценки влияния эколого-инновационной деятельности на рыночную стоимость компаний: Автореферат дисс. на соиск. уч. степени канд. эконом. наук. - М.: МЭИ, 2011. - $20 \mathrm{c}$.

33. Агеев M. K. Инструменты инновационного организационного развития: Автореферат дисс. на соиск. уч. степени канд. эконом. наук. - М.: МЭИ, 2009. - 24 с.

34. Косоротов B. A. Формирование инновационной платформы для развития розничных рынков электроэнергии: Автореферат дисс. на соиск. уч. степени канд. эконом. наук. - М.: МЭИ, 2011. - 20 с.

35. Ворожихин B. В. Организационноэкономические механизмы развития энергетики (на примере Московского региона): Автореферат дисс. на соиск. уч. степени канд. эконом. наук. - М.: Топливно-энерг. независимый ин-т, 2007. - 22 с.

36. Исмаилов С. Э. Экономические основы развития региональной энергетики: на примере Северо-Кавказского федерального округа: Автореферат дисс. на соиск. уч. степени докт. эконом. наук. - М.: Всерос. гос. налоговая акад. М-ва финансов РФ, 2012. $48 \mathrm{c}$.

37. Андрюшин Д. А. Совершенствование системы финансирования развития электроэнергетического комплекса региона на основе привлечения капитала: Автореферат дисс. на соиск. уч. степени канд. эконом. наук. - М.: МЭИ, 2003. - 18 с.

38. Гнездова Ю. В. Информационно-экономический механизм управления жилищнокоммунальным хозяйством в современных условиях (на материалах г. Смоленска): Автореферат дисс. на соиск. уч. степени канд. эконом. наук. - М.: МЭИ, 2002. - 20 с.

39. Булавин И. В. Организационно-экономическое обоснование преобразований в коммунальной энергетике (на примере Вологодской области): Автореферат дисс. на соиск. уч. степени канд. эконом. наук. - Вологда: Вологодский государственный технический университет, 2002. - 19 с.

40. Гончаров $A$. B. Стратегия регулирования рынка услуг энергоснабжения в жилищно-коммунальном хозяйстве: Автореферат дисс. на соиск. уч.степени канд. эконом. наук. - СПб.: С.-Петерб. гос. ун-т экономики и финансов, 2011. - 20 c.

41. Балябина A. А. Инструменты организации инновационной деятельности по энергосбережению в жилищно-коммунальном хозяйстве: Автореферат дисс. на соиск. уч. степени канд. эконом. наук. - М.: МЭИ, 2011. - 24 c.

42. Федеральный закон от 23.11.2009 №261-Ф3 (ред. от 25.12.2012) «Об энергосбережении и о повышении энергетической эффективности и о внесении изменений в отдельные законодательные акты РФ».

43. Апряткин B. Н. Организация управления потерями электроэнергии в распределительных электрических сетях: Автореферат дисс. на соиск. уч. степени канд. эконом. наук. - М.: Науч.-исслед. ин-т экономики энергетики, 2007. - 20 с.

44. Михайлов C. A. Методологические 
основы стратегического управления энергосбережением в региональных промышленных комплексах: Автореферат дисс. на соиск. уч. степени докт. эконом. наук. - М.: МЭИ, 2010. - 45 c.

45. Шилин B. А. Управление инновационной деятельностью в области энергосбережения и повышения энергетической эффективности регионов: Автореферат дисс. на соиск. уч. степени канд. эконом. наук. - М.: МЭИ, 2011. - $24 \mathrm{c}$.

46. Кролин A. A. Механизм и инструменты распространения инноваций в области энергосбережения: Автореферат дисс. на соиск. уч. степени канд. эконом. наук. - М.: МЭИ, 2012. - 23 с.

47. Яковлев М. М. Инновационные инструменты оценки и управления энергоэффективностью Московской агломерации: Автореферат дисс. на соиск. уч. степени канд. эконом. наук. - М.: МЭИ, 2012. - 20 с.

48. Окороков B. P. Интеллектуальные энергетические системы: технические возможности и эффективность. - Ч. 2. Проблемы российской электроэнергетики и возможности их решения на основе создания интеллектуальных энергосистем / В. Р. Окороков, И. О. Волкова, Р. В. Окороков. // Академия энергетики. - 2010. - №3 (35). - С. 74-82.

49. Вертешев A. C. Развитие интеллектуальной энергетики в России и за рубежом. // Академия энергетики. — 2011. — №1 (39). C. $70-75$.
50. Пармухина Е. Л. Рынок интеллектуальных энергосистем (Smart Grid). // Экологический вестник России. - 2011. — №1. C. 28-31.

51. Кобеи Б. Б., Волкова И. О. Smart Grid в электроэнергетике. // Энергетическая политика. - 2009. - Вып. 6. - С. 54-56.

52. Ильин В. В. Введение в Smart Grid. // АВОК. - 2012. — №7. - С. 76-80.

53. Основные виды производства электроэнергии на территории России [Электронный ресурс] / Министерство Энергетики РФ. - Режим доступа: http://minenergo.gov.ru/ activity/powerindustry/powersector/ structure/ types/, свободный. - Загл. с экрана.

54. Основы современной энергетики. В 2 ч. / Под общ. ред. чл.-корр. РАН Е. В. Аметистова. - Ч. 1. Современная теплоэнергетика / Трухний А. Д., Макаров А. А., Клименко В. В. - М.: Издательство МЭИ, 2002. - 368 с.

55. Стерман Л. С. Тепловые и атомные электрические станции: учебник для вузов по направлению «Теплоэнергетика». / Л. С. Стерман, В. М. Лавыгин, С. Г. Тишин. - 5-е изд., стереотип. - М.: Изд. дом МЭИ, 2010. $-464 \mathrm{c}$.

56. ISO 50001:2011 «Energy management systems - Requirements with guidance for use» - Geneva, Switzerland, 2011. 22 p. [Electronic resource] / International Organization for Standartization. - Mode of access: http://www.iso.org/iso/catalogue detail?csnumber $=51297$, free access.

18 декабря 2012 г.

Мария Андреевна Булатенко - аспирант кафедры Инженерного менеджмента Национального исследовательского университета «МЭИ».

Maria Andreyevna Bulatenko - postgraduate student at The Engineering Management department of The National Research University «MEI».

111250, Москва, Е-250, ул. Красноказарменная, д. 14

14 Krasnokazarmennaya st., E-250, 111250, Moscow, Russia

Тел.: +7 (495) 362-75-60; e-mail: universe@mpei.ac.ru 


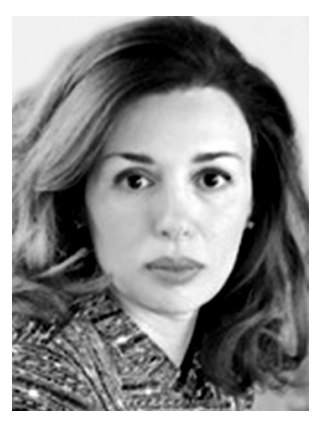

Яна Ильинична Тульчинская - кандидат экономических наук, соискатель кафедры Инженерного менеджмента Национального исследовательского университета «МЭИ». Автор ряда работ и научных исследований в области инвестирования электроэнергетической отрасли.

Yana Ilyinichna Tulchinskaya - Ph.D., Candidate of Economics, competitor for doctor's degree at The Engineering Management department of The National Research University «MEI». Author of several works and researches in the field of power sector investment.

121552, г. Москва, Островной пр., д. 3, кв. 17

3 Ostrovnoy st., app. 17, 121552, Moscow, Russia

Тел.: + 7 (925) 373-08-10; e-mail: yanka_t@hotmail.com

Конференция «еLearning elements 2013»

Дата проведения: 29.05.2013 - 30.05.2013

Место проведения: г. Москва

Программа мероприятия будет состоять из подробного рассмотрения элементов - этапов и особенностей электронного обучения, складывающихся в общую стратегию внедрения «е-learning» в организации.

Организатор: НП «Живое обучение»

\section{Контакты:}

Тел.: +7 (495) 276-08-71; e-mail: info@e-learningcenter.ru 